\title{
Foraging ecology of loggerhead sea turtles Caretta caretta in the central Mediterranean Sea: evidence for a relaxed life history model
}

\author{
Paolo Casale $^{1, *}$, Graziana Abbate ${ }^{1}$, Daniela Freggi ${ }^{2}{ }_{\text {, Nicoletta Conte }}{ }^{1}$, \\ Marco Oliverio ${ }^{1}$, Roberto Argano ${ }^{1}$
}

${ }^{1}$ Department of Animal and Human Biology, University of Rome 1 ‘La Sapienza', Viale dell'Università 32, 00185 Roma, Italy ${ }^{2}$ Sea Turtle Rescue Centre WWF Italy, Contrada Grecale, 92010 Lampedusa, Italy

\begin{abstract}
In the central Mediterranean Sea, gut contents and feces of 95 turtles captured by bottom trawlers and pelagic longliners fishing in neritic and oceanic areas, respectively, were examined. Benthic prey were more abundant than pelagic, a probable bias due to the higher digestibility of the latter. Animal and plant taxa belonging to 12 Phyla and 20 Classes were observed, with 63 new records of prey species, and Malacostraca, Gastropoda, and Echinoidea were the most commonly occurring animal classes. Results showed a highly opportunistic foraging behavior by the turtles on both live and dead material in the epipelagic zone as well as on all types of seafloor. Benthic taxa were found in turtles as small as $26 \mathrm{~cm}$ curved carapace length (CCL), indicating an early use of benthic resources, and also among turtles over a wide size range caught by pelagic longliners. The lack of evidence of a strict oceanic/ pelagic stage and of a clear habitat shift in the observed size range (25 to $80.3 \mathrm{~cm} \mathrm{CCL}$ ), when considered together with other recent findings, challenges the current ontogenetic model of life history for the species. A relaxed model is proposed, with an early short obligate epipelagic stage due to limited diving capacity, followed by the main opportunistic amphi-habitat stage, with a tendency to prefer benthic prey as turtles grow and their benthic foraging efficiency improves. Under this model, temporary or permanent association or fidelity to specific oceanic or neritic zones would vary among individuals or populations according to food availability and oceanographic features in the foraging or migratory areas.
\end{abstract}

KEY WORDS: Sea turtle $\cdot$ Caretta caretta $\cdot$ Diet $\cdot$ Life history $\cdot$ Mediterranean

\section{INTRODUCTION}

Loggerhead sea turtles Caretta caretta are a carnivorous species that prey on a great variety of animal taxa and can be considered the most generalist among sea turtles (Bjorndal 1997, 2003). They frequent different habitats and travel over vast areas during their lifetime. Juveniles prey upon epipelagic animals in the oceanic zone, and often frequent Sargassum beds (Bjorndal 1997, Bolten 2003), and they can disperse over a wide area, crossing entire oceans such as the Atlantic and the Pacific (Bowen et al. 1995, Bolten et al. 1998). Larger juveniles mainly prey upon benthic animals in neritic areas (Bjorndal 1997). It is thought that this ontogenetic habitat shift does not happen abruptly, but occurs via a transitional stage (Bolten 2003).

Understanding the ecology at species or population level is fundamental for the conservation of loggerhead turtles (listed as Endangered in the IUCN Red List of Threatened Species; www.redlist.org), because it affects individual as well as population growth (Bjorndal 2003). Moreover, different trophic resources may be affected by different anthropogenic activities, and these may represent threats additional to those currently considered (e.g. fishing) (Bjorndal 1997).

The Mediterranean Sea is small when compared with oceans, but it features both neritic and oceanic areas frequented by loggerhead turtles, which are the most common and widespread sea turtle species in the 
Mediterranean basin (Margaritoulis et al. 2003). In particular, the area between Sicily (Italy) and Africa is considered among the most important areas for loggerheads and this is where pelagic longliners and bottom trawlers capture high numbers of turtles (Casale et al. 2007a).

Diet data from different neritic areas of the basin show markedly different compositions of benthic taxa, an indication of opportunistic feeding (Laurent \& Lescure 1994, Godley et al. 1997, Tomas et al. 2001, Bentivegna et al. 2003, Lazar et al. in press). However, the ecology of loggerhead turtles in the basin is still poorly known. Laurent et al. (1998) hypothesized a transitional stage between the strictly oceanic and neritic stages, in which loggerhead turtles would feed mainly on pelagic prey but also on benthic prey, but this has not yet been adequately investigated through diet analyses. This is not a simple task, since loggerhead turtles in the neritic stage are known to feed throughthe whole water column (Bolten 2003), so that finding pelagic and benthic prey in the same sample (e.g. Tomas et al. 2001) is not proof of a transitional stage.

Small loggerhead turtles (minimum size: 29.5 and $22 \mathrm{~cm}$ respectively; Casale et al. 2004a, 2007a), have been caught by bottom trawlers in 2 of the few wide continental shelves of the Mediterranean basin, the north Adriatic and the central Mediterranean Sea, and an early recruitment to the north Adriatic neritic area was hypothesized (Casale et al. 2005a, Lazar et al. in press). On the other hand, loggerhead turtles caught by pelagic longliners have been assumed to be in the oceanic stage, in contrast to the assumption that those caught by bottom trawlers are in the neritic stage, and this has important implications for the interpretation of data and patterns in the Mediterranean Sea (e.g. Laurent et al. 1998, Margaritoulis et al. 2003). Unfortunately, the feeding ecology of loggerhead turtles caught by pelagic longliners in the Mediterranean Sea has not yet been investigated.

By means of dietary analyses of loggerhead turtles caught by bottom trawlers and by pelagic longliners in this unique area (a limited oceanic zone and a wide continental shelf), this study aims to provide insights into the loggerhead turtle foraging strategy, oceanic habitat stage, and the shift to a neritic habitat through a possible transitional stage, in the wider context of the species' ecological flexibility.

\section{MATERIALS AND METHODS}

In the period 2001 to 2005, mostly in summer, 95 loggerhead turtles Caretta caretta caught by bottom trawlers $(n=39)$, drifting longliners $(n=31)$, or found floating at sea or in other circumstances $(n=25)$, were brought to the WWF's Turtle Rescue Centre in Lampedusa Island, Italy (Fig. 1), and kept under observation for variable periods of time. No exact information on the place of capture is available, however longliners typically fish in open waters off the continental shelves, while trawlers fish in shallow waters on the shelves, so that loggerhead turtles caught by these 2 gears are assumed to have been either in the oceanic or neritic zones, respectively. Of the 95 loggerhead turtles considered, 36 were either found dead, or died later of various (mostly anthropogenic) causes. The curved carapace length (CCL) of all turtles was measured notch-to-tip (CCLn-t, Bolten 1999).

Live turtles were kept in separate tanks and checked 4 times per day. If present, feces samples were collected using a net of $0.4 \mathrm{~mm}$ mesh. Dead turtles were preserved frozen $\left(-20^{\circ} \mathrm{C}\right)$ and then defrosted before necropsy. The whole digestive tract was opened, and any material found inside was collected. In total, samples from 79 loggerhead turtles were collected: 33 gut content samples from dead turtles and 47 fecal samples from live turtles ( 1 turtle provided both feces and gut contents). The other 16 turtles did not defecate $(n=14)$ or had empty digestive tracts $(n=2)$. These turtles were included in the analysis because it could not be excluded that they had fed upon highly digestible pelagic prey, leaving no residuals.

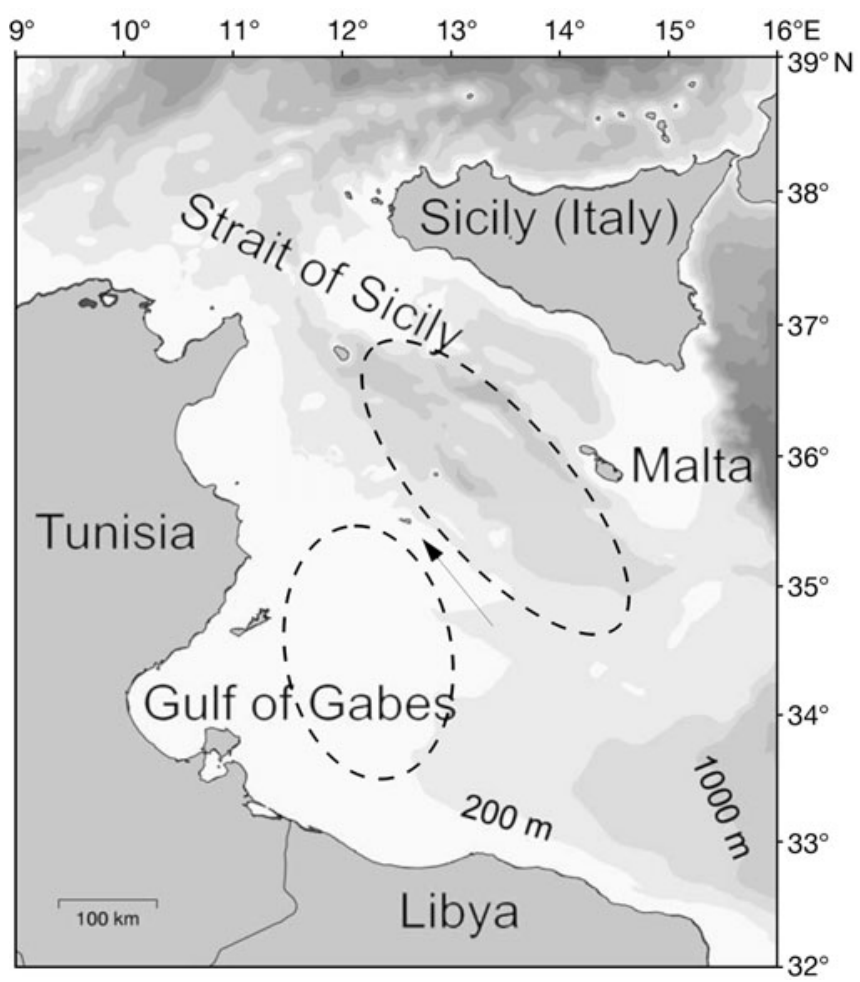

Fig. 1. Study area. The arrow indicates Lampedusa Island (Italy). Dashed lines show the approximate areas of fishing for trawlers (south) and longliners (north) 
Samples were either preserved frozen, then defrosted and put in formaldehyde $10 \%$, or put directly in formaldehyde. Samples were rinsed with water and filtered through a net of $0.4 \mathrm{~mm}$ mesh. Where samples contained abundant material $<1 \mathrm{~mm}$ (separated by filtering with $1 \mathrm{~mm}$ mesh sieve), a randomly selected subsample of this material was examined. Samples were preserved in $75 \%$ ethanol and then identified to the lowest taxonomic level possible by eye, stereomicroscope $(40 \times)$, or microscope $(1000 \times)$. Samples not identifiable were labeled as 'not identified'. In this way, for each turtle, a set of samples including only one category each (a specific taxon or anthropogenic debris or natural material) were obtained. Fish and squid were excluded from further analyses because their occurrence might in part have been an artifact, since both could have been longline bait, and fish was the food supplied at the rescue center.

Samples were briefly placed on a $0.4 \mathrm{~mm}$ mesh sieve to drain excess water and then weighed to $0.1 \mathrm{~g}$ accuracy using a balance wet weight (wet wt). They were then dried in an oven at $60^{\circ} \mathrm{C}$ for $48 \mathrm{~h}$ and weighed again to determine dry weight (dry wt). Samples $<0.1 \mathrm{~g}$ were considered as 'traces'.

Species were considered to be new food items if not previously reported in the literature (Mortimer 1982, Dodd 1988, Burke et al. 1990, Laurent \& Lescure 1994, Plotkin 1996, Bjorndal 1997, Godley et al. 1997, Frick et al. 2001, Limpus et al. 2001, Tomas et al. 2001, Lazar et al. 2002, Witherington 2002, Bentivegna et al. 2003, Bugoni et al. 2003, Seney et al. 2003, Parker et al. 2005). Whenever possible, taxa were classified as benthic or pelagic. Anthropogenic debris (e.g. plastic) and natural material not belonging to marine organisms (e.g. wood) were classified as 'floating' or 'sinking' through buoyancy tests in water.

Taxonomic diversity in the samples was analysed at 3 different levels: 2 levels corresponding to formal taxonomic categories (class and species), including the samples discriminated at the respective level, and 1 level including all taxa identified independently of their taxonomic level and considered as Operational Taxonomic Units, OTUs. The frequency of occurrence (Hyslop 1980) of classes, species and OTUs was calculated. Herrera's (1976) trophic diversity index was calculated for all these 3 categories as: $\mathrm{D}=-\Sigma \ln p_{i}$ where $p_{i}$ is the frequency of occurrence of the ith trophic item.

\section{RESULTS}

Loggerhead turtles caught by bottom trawlers were on average $59 \mathrm{~cm}$ CCLn-t (SD: 9, range: 41 to $80.3 \mathrm{~cm}$, $\mathrm{n}=39$ ) and larger than those caught by pelagic longliners $(44.9 \mathrm{~cm}$; SD: 11.9 , range: 25 to $76.2 \mathrm{~cm}, \mathrm{n}=31$ )
(Mann-Whitney $U$-test; $\mathrm{p}<0.001, \mathrm{n}=70$ ), while those found in other circumstances were $51.4 \mathrm{~cm}$ (SD: 13.3, range: 24 to $79 \mathrm{~cm}, \mathrm{n}=25$ ). Since it is thought that Mediterranean loggerhead turtles mature when larger than $70 \mathrm{~cm}$ CCLn-t (Margaritoulis et al. 2003, Casale et al. 2005b), most of our turtles were probably juveniles.

Animals and plants from 12 Phyla and 20 Classes were found among the ingested marine organisms. Three samples could only be identified to the phylum level, while 144 were identified to at least the class level, 91 of which were further identified to species level (see Appendix 1, available in MEPS Supplementary Material at www.int-res.com/articles/suppl/ m372p265_app.pdf). Of these, 63 species have not been previously reported among loggerhead turtle food items.

Occurrence of identified prey species in turtles ranged from 1.3 to $29.1 \%$ of all turtles sampled (Appendix 1). Among the animal classes, Malacostraca, Gastropoda, Echinoidea and Osteichthyes (the latter excluded from further analysis because possibly an artifact; see 'Materials and methods') were found in more than $50 \%$ of the turtles (Table 1). However, these classes were particularly abundant among turtles captured by only one of the 2 fishing methods (for all 4 classes: Fisher's exact test; $\mathrm{p}<0.01, \mathrm{n}=62$ ): the first 3 classes were found in $80 \%$ or more of the turtles captured by trawlers, while the 4 th was found in $70 \%$ of the turtles captured by longliners.

Number of prey classes, species, and OTUs varied among individual turtles (Table 2). Turtles caught by trawl had ingested more classes (Mann-Whitney $U$ test; $\mathrm{p}<0.001, \mathrm{n}=58$ ), species (Mann-Whitney $U$-test; $\mathrm{p}<0.001, \mathrm{n}=46$ ), and OTUs (Mann-Whitney $U$-Test; $\mathrm{p}<0.001, \mathrm{n}=58$ ) than those caught by longliners. Diversity of classes and OTUs was higher in turtles caught by trawlers than by longliners (Table 2).

Number of classes, species, and OTUs were highly correlated with turtle size (For all 3 groups: Spearman correlation test; $\mathrm{p}<0.001, \mathrm{n}=71,60$, and 73, respectively). Within longline and trawl groups, no correlation of number of classes with size was detected (Spearman correlation test; $\mathrm{n}=23$ and 35, respectively), while correlation was found for the number of species and OTUs in the trawl group (for species and OTUs: Spearman correlation test; $\mathrm{p}<0.05, \mathrm{n}=35$ ), but not in the longline group (for species and OTUs: Spearman correlation test; $\mathrm{n}=11$ and 23 , respectively).

Natural organic material other than marine organisms included bird feathers and wood. Anthropogenic debris was present in $48.1 \%$ of turtles (Table 1) and included mainly plastic (nylon, fishing line, bags, labels, bands, bottle stopper, tubes, plastic for packing) and also tar, pieces of net, paint, polystyrene, plasters and a hook. 
Table 1. Caretta caretta. Occurrence (\%) of different taxa and other material in gut and fecal samples from turtles caught by longliners, trawlers, found floating or under other circumstances

\begin{tabular}{|c|c|c|c|c|c|c|c|c|c|c|c|c|}
\hline \multirow[t]{2}{*}{ Category } & \multicolumn{3}{|c|}{ — Longline } & \multicolumn{3}{|c|}{$\longrightarrow$ Trawl $\longrightarrow$} & \multicolumn{3}{|c|}{ - Other } & \multicolumn{3}{|c|}{ - Total - } \\
\hline & Gut & Feces & Total & Gut & Feces & Total & Gut & Feces & Total & Gut & Feces & Total \\
\hline \multicolumn{13}{|l|}{ Animalia } \\
\hline \multicolumn{13}{|l|}{ Porifera } \\
\hline Demospongiae & 7.1 & 7.7 & 7.4 & 77.8 & 23.1 & 37.1 & 20.0 & 12.5 & 16.7 & 30.3 & 17.0 & 22.8 \\
\hline \multicolumn{13}{|l|}{ Cnidaria } \\
\hline$\overline{\text { Anthozoa }}$ & 0.0 & 0.0 & 0.0 & 44.4 & 3.8 & 14.3 & 0.0 & 0.0 & 0.0 & 12.1 & 2.1 & 6.3 \\
\hline Scyphozoa & 0.0 & 0.0 & 0.0 & 0.0 & 0.0 & 0.0 & 10.0 & 0.0 & 5.6 & 3.0 & 0.0 & 1.3 \\
\hline \multicolumn{13}{|l|}{ Platyhelminthes } \\
\hline Turbellaria & 0.0 & 0.0 & 0.0 & 0.0 & 0.0 & 0.0 & 10.0 & 0.0 & 5.6 & 3.0 & 0.0 & 1.3 \\
\hline$\underline{\text { Sipunculida }}$ & 0.0 & 0.0 & 0.0 & 0.0 & 3.8 & 2.9 & 0.0 & 0.0 & 0.0 & 0.0 & 2.1 & 1.3 \\
\hline \multicolumn{13}{|l|}{ Mollusca } \\
\hline$\overline{\text { Bivalvia }}$ & 7.1 & 0.0 & 3.7 & 66.7 & 84.6 & 80.0 & 0.0 & 12.5 & 5.6 & 21.2 & 48.9 & 38.0 \\
\hline Gastropoda & 21.4 & 38.5 & 29.6 & 88.9 & 96.2 & 94.3 & 20.0 & 37.5 & 27.8 & 39.4 & 70.2 & 58.2 \\
\hline Cephalopoda & 7.1 & 30.8 & 18.5 & 22.2 & 19.2 & 20.0 & 20.0 & 25.0 & 22.2 & 21.2 & 25.5 & 24.1 \\
\hline \multicolumn{13}{|l|}{ Annelida } \\
\hline Polychaeta & 0.0 & 7.7 & 3.7 & 33.3 & 50.0 & 45.7 & 0.0 & 12.5 & 5.6 & 9.1 & 31.9 & 22.8 \\
\hline \multicolumn{13}{|l|}{ Arthropoda } \\
\hline Malacostraca & 14.3 & 46.2 & 29.6 & 66.7 & 96.2 & 88.6 & 50.0 & 50.0 & 50.0 & 39.4 & 74.5 & 60.8 \\
\hline \multicolumn{13}{|l|}{ Tentaculata } \\
\hline$\overline{\text { Bryozoa }}$ & 0.0 & 7.7 & 3.7 & 22.2 & 26.9 & 25.7 & 0.0 & 0.0 & 0.0 & 6.1 & 17.0 & 12.7 \\
\hline \multicolumn{13}{|l|}{ Echinodermata } \\
\hline Echinoidea & 21.4 & 53.8 & 37.0 & 66.7 & 84.6 & 80.0 & 0.0 & 50.0 & 22.2 & 27.3 & 70.2 & 53.2 \\
\hline Holothuroidea & 0.0 & 0.0 & 0.0 & 11.1 & 0.0 & 2.9 & 0.0 & 0.0 & 0.0 & 3.0 & 0.0 & 1.3 \\
\hline Ophiuroidea & 0.0 & 0.0 & 0.0 & 0.0 & 3.8 & 2.9 & 0.0 & 0.0 & 0.0 & 0.0 & 2.1 & 1.3 \\
\hline \multicolumn{13}{|l|}{ Chordata } \\
\hline$\overline{\text { Ascidiacea }}$ & 7.1 & 0.0 & 3.7 & 22.2 & 30.8 & 28.6 & 10.0 & 0.0 & 5.6 & 12.1 & 17.0 & 15.2 \\
\hline Chondrichthyes & 7.1 & 0.0 & 3.7 & 0.0 & 0.0 & 0.0 & 0.0 & 0.0 & 0.0 & 3.0 & 0.0 & 1.3 \\
\hline Osteichthyes & 57.1 & 84.6 & 70.4 & 44.4 & 26.9 & 31.4 & 50.0 & 75.0 & 61.1 & 51.5 & 51.1 & 50.6 \\
\hline Plantae & 14.3 & 0.0 & 7.4 & 0.0 & 0.0 & 0.0 & 10.0 & 0.0 & 5.6 & 9.1 & 0.0 & 3.8 \\
\hline Phycophyta & 0.0 & 30.8 & 14.8 & 33.3 & 73.1 & 62.9 & 20.0 & 62.5 & 38.9 & 15.2 & 59.6 & 41.8 \\
\hline Rhodophyceae & 7.1 & 30.8 & 18.5 & 66.7 & 92.3 & 85.7 & 20.0 & 50.0 & 33.3 & 27.3 & 68.1 & 51.9 \\
\hline Phaeophyceae & 57.1 & 23.1 & 40.7 & 33.3 & 19.2 & 22.9 & 10.0 & 12.5 & 11.1 & 36.4 & 19.1 & 26.6 \\
\hline Chlorophyceae & 0.0 & 0.0 & 0.0 & 22.2 & 0.0 & 5.7 & 0.0 & 0.0 & 0.0 & 6.1 & 0.0 & 2.5 \\
\hline \multicolumn{13}{|l|}{ Spermatophyta } \\
\hline Monocotyledoneae & 28.6 & 38.5 & 33.3 & 0.0 & 15.4 & 11.4 & 20.0 & 37.5 & 27.8 & 18.2 & 25.5 & 22.8 \\
\hline \multicolumn{13}{|l|}{ Other material } \\
\hline Bird feathers & 14.3 & 7.7 & 11.1 & 0.0 & 0.0 & 0.0 & 0.0 & 0.0 & 0.0 & 6.1 & 2.1 & 2.5 \\
\hline Wood & 7.1 & 30.8 & 18.5 & 11.1 & 11.5 & 11.4 & 20.0 & 25.0 & 22.2 & 12.1 & 19.1 & 16.5 \\
\hline Anthropogenic debris & 64.3 & 46.2 & 55.6 & 22.2 & 34.6 & 31.4 & 60.0 & 75.0 & 66.7 & 51.5 & 44.7 & 48.1 \\
\hline Stones/pebbles & 0.0 & 7.7 & 3.7 & 22.2 & 38.5 & 34.3 & 0.0 & 25.0 & 11.1 & 6.1 & 27.7 & 19.0 \\
\hline Sand/mud & 14.3 & 53.8 & 33.3 & 55.6 & 53.8 & 54.3 & 0.0 & 25.0 & 11.1 & 21.2 & 48.9 & 36.7 \\
\hline Not identified & 78.6 & 23.1 & 51.9 & 33.3 & 34.6 & 34.3 & 30.0 & 37.5 & 33.3 & 51.5 & 31.9 & 40.5 \\
\hline No. turtles analysed (N) & 14 & 13 & 27 & 9 & 26 & 35 & 10 & 8 & 18 & 33 & 47 & 79 \\
\hline
\end{tabular}

The mean wet wt of ingested material in the 79 loggerhead turtles was $110.8 \mathrm{~g}$ (range: 0.7 to $693.5 \mathrm{~g}$ ) and mean dry wt was $46.6 \mathrm{~g}$ (range: 0.2 to $354.1 \mathrm{~g}$ ). Echinoidea, Gastropoda and Malacostraca were the most abundant classes in weight, each accounting for more than $10 \%$ of total wet wt and dry wt (Table 3).

Benthic taxa were more frequent than pelagic taxa in all 3 capture categories (longline, trawl, and other; Table 4). However, benthic taxa were more frequent among turtles caught by trawlers than by longliners (Fisher's exact test; $\mathrm{p}<0.01, \mathrm{n}=61$ ), while for pelagic taxa, the opposite was the case (Fisher's exact test; $\mathrm{p}<$ $0.05, \mathrm{n}=61$ ).

The same pattern was observed for natural material not belonging to marine organisms, with sinking material being more frequent than floating material in all 3 capture categories, and sinking material being more frequent among turtles caught by trawlers than by longliners (Fisher's exact test; $\mathrm{p}<$ $0.05, \mathrm{n}=37$ ), while for floating material the opposite was the case (Fisher's exact test; $\mathrm{p}<0.05, \mathrm{n}=37$ ) (Table 4). 
Table 2. Caretta caretta. Number of Classes, Species and operational taxonomic units (OTUs) (mean $\pm \mathrm{SD}$ ) identified in turtles captured under different circumstances (by longliners or trawlers). The 'All' category includes all turtles, whichever way they were collected (i.e. also those found floating). D: Herrera's diversity index; $N$ : number of turtles examined

\begin{tabular}{|lrrrrr|}
\hline & Mean & \pm SD & Range & D & $\mathrm{N}$ \\
\hline Class & & & & & \\
Longline & 2.8 & 1.5 & $1-6$ & 28.2 & 23 \\
Trawl & 6.5 & 2.1 & $1-11$ & 25.7 & 35 \\
All & 4.8 & 2.6 & $1-11$ & 48.5 & 71 \\
Species & & & & & \\
Longline & 3.0 & 3.7 & $1-14$ & 60.6 & 11 \\
Trawl & 8.1 & 6.2 & $1-28$ & 215.1 & 35 \\
All & 5.9 & 5.7 & $1-28$ & 315.0 & 60 \\
OTUs & & & & & \\
Longline & 3.7 & 3.5 & $1-18$ & 119.0 & 23 \\
Trawl & 15.3 & 9.6 & $1-47$ & 327.8 & 35 \\
All & 9.6 & 9.2 & $1-47$ & 499.6 & 73 \\
\hline
\end{tabular}

In contrast, floating anthropogenic debris was more abundant than sinking debris (Table 4), a significant difference from natural material (the other non-prey category) (Fisher's exact test; $\mathrm{p}<0.01, \mathrm{n}=89$ ). No difference in floating anthropogenic debris was detectable between longliners and trawlers (Fisher's exact test; not significant, $\mathrm{n}=25$ ).

As a whole, material assumed to have been ingested at the seafloor (i.e. benthic taxa, sinking natural material, and sinking anthropogenic debris) was more frequent among turtles captured by trawlers than by longliners (Fisher's exact test; $\mathrm{p}<0.05, \mathrm{n}=61$ ).

Among loggerhead turtles that ingested benthic organisms, epibiont balanomorph barnacles (possible indicators of habitats frequented; see 'Discussion') were found on the carapace of $74 \%$ of turtles caught by trawlers $(\mathrm{n}=35)$, but only on $5 \%$ of turtles caught by longliners $(\mathrm{n}=20)$ (Fisher's exact test; $\mathrm{p}<$ 0.01, $\mathrm{n}=55$ ).

Benthic taxa occured in at least $50 \%$ of turtles in each size class (Fig. 2), and the smallest turtle with ingested benthic taxa was $26 \mathrm{~cm}$ CCLn-t. If all material assumed to have been found at the seafloor is considered, occurrence was higher than $60 \%$ in each size class (Fig. 3) and the smallest turtle was $25 \mathrm{~cm}$ CCLn-t.

\section{DISCUSSION}

\section{Diet, foraging patterns, and benthic habitats}

Gut and fecal samples are the result of a partial or total digestion process. That does not necessarily mean that the samples are always completely digested, since
Table 3. Caretta caretta. Percentage of wet weight (wet wt) and dry weight (dry wt) of different taxa and other material in the 79 turtle gut content samples

\begin{tabular}{|c|c|c|}
\hline Category & $\overline{\text { Wet wt }(\mathrm{g})}$ Total & Dry wt $(g)$ \\
\hline \multicolumn{3}{|l|}{ Animalia } \\
\hline \multicolumn{3}{|l|}{ Porifera } \\
\hline Demospongiae & 8.3 & 3.9 \\
\hline \multicolumn{3}{|l|}{ Cnidaria } \\
\hline Anthozoa & 0.2 & 0.1 \\
\hline Scyphozoa & 0.0 & 0.0 \\
\hline \multicolumn{3}{|l|}{ Platyhelminthes } \\
\hline Turbellaria & 0.0 & 0.0 \\
\hline Sipunculida & 0.0 & 0.0 \\
\hline \multicolumn{3}{|l|}{ Mollusca } \\
\hline Bivalvia & 0.3 & 0.3 \\
\hline Gastropoda & 11.9 & 19.6 \\
\hline Cephalopoda & 4.3 & 2.0 \\
\hline \multicolumn{3}{|l|}{ Annelida } \\
\hline Polychaeta & 0.2 & 0.3 \\
\hline \multicolumn{3}{|l|}{ Arthropoda } \\
\hline Malacostraca & 13.8 & 11.0 \\
\hline \multicolumn{3}{|l|}{ Tentaculata } \\
\hline Bryozoa & 0.1 & 0.1 \\
\hline \multicolumn{3}{|l|}{ Echinodermata } \\
\hline$\overline{\text { Echinoidea }}$ & 38.9 & 46.1 \\
\hline Holothuroidea & 0.4 & 0.2 \\
\hline Ophiuroidea & 0.0 & 0.0 \\
\hline \multicolumn{3}{|l|}{ Chordata } \\
\hline Ascidiacea & 11.7 & 6.7 \\
\hline Chondrichthyes & 0.0 & 0.0 \\
\hline Plantae & 0.3 & 0.1 \\
\hline Phycophyta & 1.0 & 0.4 \\
\hline Rhodophyceae & 1.3 & 1.6 \\
\hline Phaeophyceae & 0.4 & 0.1 \\
\hline Chlorophyceae & 0.0 & 0.0 \\
\hline \multicolumn{3}{|l|}{ Spermatophyta } \\
\hline Monocotyledoneae & 0.2 & 0.1 \\
\hline \multicolumn{3}{|l|}{ Other material } \\
\hline Bird feathers & 0.0 & 0.0 \\
\hline Wood & 0.1 & 0.1 \\
\hline Anthropogenic debris & 1.7 & 1.7 \\
\hline Stones/pebbles & 0.9 & 1.7 \\
\hline Sand/mud & 2.2 & 2.3 \\
\hline Not identified & 1.7 & 1.5 \\
\hline Total & 8748 & 3684.5 \\
\hline
\end{tabular}

partly digested elements were commonly observed in feces. Certainly, soft tissues of part of, or even whole, individual prey were under-represented in our samples. As a consequence, our results are probably biased towards and more informative of benthic taxa, which typically have harder components than pelagic taxa.

Among benthic taxa, Malacostraca, Gastropoda and Echinoidea seem to be the most important prey classes, both in occurrence (they were found in most of the turtles; Table 1) and total weight (Table 3). However, Malacostraca were largely represented by 
Table 4. Caretta caretta. Occurrence (\%) of taxa, natural material, and anthropogenic debris classified according to the zone were they were probably ingested (sea bottom vs. surface) among gut and fecal samples from turtles caught by longline, trawlers, or found in other circumstances. Turtles with no gut or fecal material were conservatively included because possible pelagic prey may have not been detected (see 'Materials and Methods')

\begin{tabular}{|c|c|c|c|c|c|c|c|c|c|c|c|c|}
\hline \multirow{2}{*}{ Category } & \multicolumn{3}{|c|}{ - Longline___ } & \multicolumn{3}{|c|}{ Trawl } & \multicolumn{3}{|c|}{ - Other } & \multicolumn{2}{|r|}{ - Total } & \multirow{2}{*}{ Total } \\
\hline & Gut & Feces & Total & Gut & Feces & Total & Gut & Feces & Total & Gut & Feces & \\
\hline Benthic taxa & 53.3 & 70.6 & 52.6 & 100.0 & 86.7 & 81.4 & 63.6 & 42.9 & 58.3 & 71.4 & 72.1 & 72.6 \\
\hline Pelagic taxa & 53.3 & 17.6 & 28.9 & 11.1 & 13.3 & 14.0 & 18.2 & 7.1 & 20.8 & 31.4 & 13.1 & 23.2 \\
\hline Other & 26.7 & 5.9 & 0.0 & 0.0 & 0.0 & 0.0 & 18.2 & 14.3 & 0.0 & 14.3 & 4.9 & 7.4 \\
\hline Total benthic/pelagic & 66.7 & 70.6 & 68.4 & 100.0 & 86.7 & 81.4 & 72.7 & 42.9 & 75.0 & 80.0 & 72.1 & 75.8 \\
\hline Sinking natural material & 13.3 & 47.1 & 23.7 & 66.7 & 60.0 & 55.8 & 0.0 & 28.6 & 16.7 & 22.9 & 49.2 & 38.9 \\
\hline Floating natural material & 20.0 & 29.4 & 18.4 & 11.1 & 10.0 & 9.3 & 18.2 & 14.3 & 16.7 & 17.1 & 16.4 & 15.8 \\
\hline Other & 66.7 & 17.6 & 34.2 & 33.3 & 26.7 & 25.6 & 72.7 & 28.6 & 50.0 & 60.0 & 24.6 & 37.9 \\
\hline Total natural material & 26.7 & 58.8 & 34.2 & 66.7 & 60.0 & 55.8 & 18.2 & 28.6 & 25.0 & 34.3 & 52.5 & 45.3 \\
\hline $\begin{array}{l}\text { Sinking anthropogenic } \\
\text { debris }\end{array}$ & 0.0 & 5.9 & 2.6 & 11.1 & 6.7 & 7.0 & 9.1 & 0.0 & 4.2 & 5.7 & 4.9 & 5.3 \\
\hline $\begin{array}{l}\text { Floating anthropogenic } \\
\text { debris }\end{array}$ & 53.3 & 29.4 & 34.2 & 22.2 & 23.3 & 20.9 & 36.4 & 42.9 & 41.7 & 40.0 & 29.5 & 33.7 \\
\hline Other & 40.0 & 41.2 & 31.6 & 77.8 & 56.7 & 55.8 & 45.5 & 14.3 & 29.2 & 51.4 & 42.6 & 45.3 \\
\hline $\begin{array}{l}\text { Total anthropogenic } \\
\text { debris }\end{array}$ & 53.3 & 35.3 & 36.8 & 22.2 & 30.0 & 25.6 & 45.5 & 42.9 & 45.8 & 42.9 & 34.4 & 37.9 \\
\hline Total bottom & 60.0 & 76.5 & 55.3 & 100.0 & 86.7 & 81.4 & 63.6 & 50.0 & 62.5 & 74.3 & 75.4 & 74.7 \\
\hline Total surface & 80.0 & 52.9 & 52.6 & 22.2 & 33.3 & 30.2 & 45.5 & 42.9 & 54.2 & 54.3 & 41.0 & 45.3 \\
\hline No material & 6.7 & 23.5 & 31.6 & 0.0 & 13.3 & 18.6 & 9.1 & 42.9 & 25.0 & 5.7 & 23.0 & 16.8 \\
\hline Turtles (N) & 15 & 17 & 38 & 9 & 30 & 43 & 11 & 14 & 24 & 35 & 61 & 95 \\
\hline
\end{tabular}

the family Paguridae (found in 43 out of 48 turtles with Malacostraca) which typically live in gastropod shells. Although gastropod opercula (both corneous and calcareous) were found in some samples, indicating that turtles had ingested gastropods and not hermit crabs, opercula (particularly the corneous type) can be digested, and both hermit crabs (Frick et al. 2001) and opercula can be lost during the repeated opening and closing of the beak typical of food seizure and manipulation. Thus, in many cases, it was difficult to assess whether a gastropod or a hermit crab had been ingested and whether loggerhead turtles target hermit crabs, gastropods, or both (see also Frick et al. 2001). This makes the type of seafloor frequented by loggerhead turtles that have ingested gastropods uncertain, because hermit crabs do not necessarily live on the same seafloor as the gastropod whose shells they use.

Although Bivalvia were found in $38 \%$ of the turtles (Table 1), their total weight was just $0.3 \%$ of that of all taxa combined, despite the fact that this taxon has hard parts as well; this suggests that Bivalvia may have a limited importance in the diet and may be ingested accidentally by loggerheads feeding on other prey. On the other hand, Ascidiacea typically have soft bodies and were probably under-represented in the samples; yet they occurred in $15.2 \%$ of turtles and represented $11.4 \%$ of wet wt, suggesting a high importance of this class in the diet.
Sponges were found in many turtles $(22.8 \%$; Table 1), but in all cases they were completely undigested, confirming that loggerhead turtles are unable to digest sponges (in contrast to hawksbill turtles; Bjorndal 1997). Possible explanations for the ingestion of sponges are (1) the symbiosis between the sponge Suberites domuncula and the hermit crab Paguristes oculatus, which could be the real target prey, (2) the accidental ingestion while feeding on other prey, (3) the sponges are a source of bacterial fauna or oligoelements (as suggested by Laurent \& Lescure 1994).

Algae and plants were found in most (66) turtles, but in all cases they were completely undigested, confirming that the loggerhead turtle is a strictly carnivorous species and unable to digest organisms of vegetal origin, which are probably ingested accidentally while feeding on animal prey.

Several findings provide interesting clues about the foraging strategy of loggerhead turtles in our study area. First, the high number of new records of prey species found as well as the different occurrences of taxa such as Echinoidea $(53.2 \%, \mathrm{n}=79)$ in comparison to another Mediterranean area (Western Basin; $3.7 \%, \mathrm{n}=54$; Tomas et al. 2001) or the same area in a different period or season (possible confounding factors due to possible changes in prey availability) (winter: $9.7 \%, \mathrm{n}=31$; Laurent \& Lescure 1994) indicate a highly opportunistic strategy. Second, this opportunism probably extends to all possible sources of 

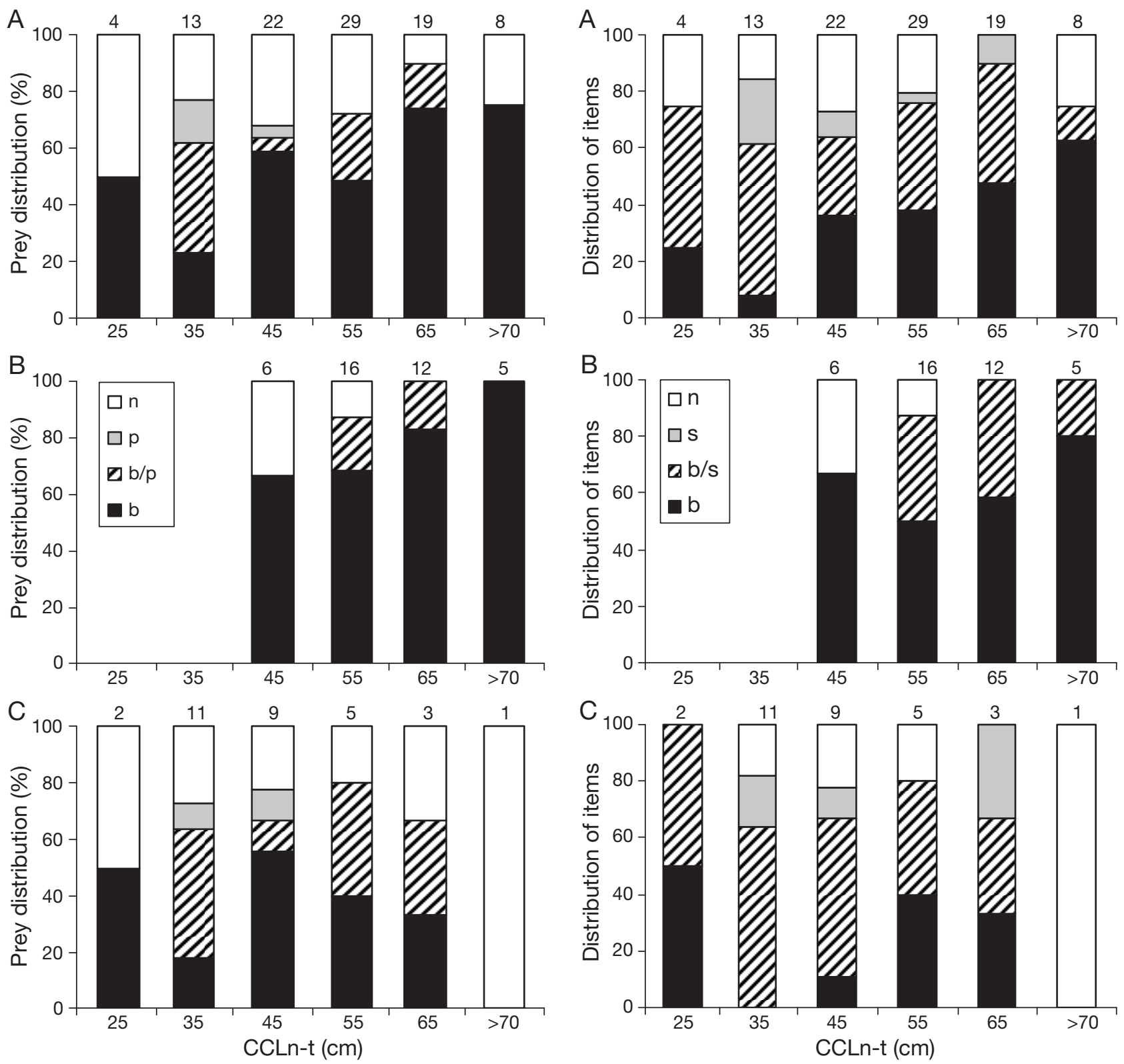

Fig. 2. Caretta caretta. Distribution of prey items (\%) in gut content and fecal samples among different size classes (CCLn-t) of loggerhead turtles $(\mathrm{n}=95)$. (b) Benthic taxa, (p) pelagic taxa, (b/p) both or (n) no marine taxa. (A) All turtles; (B) turtles caught by trawlers $(\mathrm{n}=39)$; (C) turtles caught by longliners $(\mathrm{n}=31)$. The number of turtles per size class is indicated above the bars

animal material, including carcasses. In fact, samples from 7 turtles included necrophagous gastropods of the genus Nassarius associated with other benthic taxa, an indication that those turtles fed on dead benthic organisms found on the seafloor, as also suggested by Shaver (1991). Scavenging on dead organisms, including fishing discards, was hypothesized by several studies (e.g. Limpus et al. 2001, Tomas et al.

Fig. 3. Caretta caretta. Distribution of ingested items (\%) of different origin among loggerhead turtles size classes (CCLn-t, $\mathrm{n}=95$ ) (b) probably ingested at the sea bottom, (s) at the sea surface, (b/s) both or (n) with no material. (A) All turtles; (B) turtles caught by trawlers $(\mathrm{n}=39)$; $(\mathrm{C})$ turtles caught by longliners $(n=31)$. The number of turtles per size class is indicated above the bars

2001). This is probably the reason why longlines, with their hooks baited with dead squid or fish, capture so many loggerhead turtles globally (Lewison et al. 2004).

All these findings confirm and support the opportunistic foraging strategy of loggerhead turtles reported by previous studies in other areas (e.g. Tomas et al. 2001). 
Our results suggest that, in our study area, loggerhead turtles in the observed size range feed throughout the entire water column, from the bottom to the surface, as indicated by benthic and pelagic prey and by the natural and anthropogenic floating and sinking material found in gut and feces samples.

The results also provide clues about the benthic habitats frequented. The high occurrence of algal and plant taxa generally suggests that loggerhead turtles frequent mainly shallow areas, within a few 10s of meters (Appendix 1), where there is sufficient light for these taxa. For instance, Phanerogam beds (Posidonia oceanica and Cymodocea nodosa) have a particularly shallow depth range (0 to $35 \mathrm{~m}$ ), and samples from many turtles contained these species or animal species typically associated with these beds, such as the gastropods Gibbula philberti and Jujubinus unidentatus, the sea urchins Sphaerechinus granularis, Echinocyamus pusillus and Centrostephanus longirostris, and the sponge Suberites domuncula. Hence, Phanerogam beds appear to be highly frequented by loggerhead turtles in the area, and this has important implications for conservation, since the protection of these habitats would benefit a wide biological community, including turtles.

Other prey species have a deeper distribution (Appendix 1), suggesting that loggerhead turtles feed on the seafloor at $100 \mathrm{~m}$ depth or even deeper. However, it cannot be excluded that a portion of these prey species is bycatch discarded by trawlers fishing in the area. Concerning the type of bottom, the prey species found indicate that loggerhead turtles search for food in a variety of habitats in addition to Phanerogam beds, such as rocky bottoms (Bolma rugosa, Serpula vermicularis, Ascidia involuta, Ascidiella aspersa, Arbacia lixula), gorges and caves (Astroides calicularis and Cladocora cespidosa), and in mud/sand bottoms (Holoturia forskali, Echinocardium cordatum, and Spatangus purpureus). The latter 2 species are infaunal species living burrowed in the sand; possibly the turtles prey on them using the 'infaunal mining' method described by Preen (1996) from Queensland, Australia, which consists of digging deep and long canals in the sand with their forelimbs.

\section{Anthropogenic debris}

Anthropogenic debris was found in $48.1 \%$ of the turtles with gut contents or feces $(n=79$; Table 1$)$. This indicates that debris consumption is common in loggerhead turtles frequenting the central Mediterranean, but less common than in the western Mediterranean Sea, where Tomas et al. (2002) observed anthropogenic debris in $75.9 \%$ of 54 turtles caught by trawlers (in the present study, the occurrence in the trawl group was $31.4 \%$ ). This difference may be indicative of a different degree of pollution in the 2 areas.

Most debris was of the floating kind, and this can have 2 explanations: either this category represents most of the anthropogenic debris discarded at sea in this area, or loggerhead turtles are more attracted by floating debris than by debris on the seafloor.

The negative impact of this debris on loggerhead turtles is uncertain. The highest amount of plastic found in a single individual, which probably died for this reason, was $47.5 \mathrm{~g}$ (wet wt; mostly floating plastic), but for the other turtles it was much lower. Although debris might kill turtles in some cases, sublethal effects, if any, such as the reduced energy and nitrogen intake due to dietary dilution observed in post-hatchlings by McCauley \& Bjorndal (1999), seem more likely.

\section{Epipelagic and benthic habitat use}

Loggerhead turtles are believed to undergo an oceanic stage in their first period of life, in which they live in the epipelagic and oceanic zone and prey upon pelagic organisms. This is followed by a neritic stage, in which they live in the neritic zone and mainly prey upon benthic organisms (Bolten 2003). Since longliners typically fish in open waters off the continental shelves and catch smaller turtles while trawlers fish in shallow waters on the continental shelves and catch larger turtles, these 2 fishing methods were associated with the oceanic and neritic stages of turtles, respectively (e.g. Laurent et al. 1998).

However, in the present study, benthic taxa or material probably found at the sea bottom were found in high proportions in all size classes observed (Figs. 2 $\& 3)$. In addition, pelagic prey or floating material was found in most size classes (Figs. 2 \& 3), indicating that the turtles never stop feeding throughout the entire water column. Within the observed size range, larger loggerhead turtles appear to feed more on benthic prey than small turtles (Figs. $2 \& 3$ ), and the diversity of prey species (mostly benthic) increases with increasing turtle size, also among turtles caught by bottom trawlers only. These 2 findings indicate a higher exploitation of benthic resources as turtles grow, suggesting a slow change in the preferred habitat across a wide size range, rather than stages with a clear preference for a specific habitat.

However, the higher occurrence of benthic taxa observed among turtles caught by trawlers than by longliners, while the opposite was observed for pelagic taxa, indicate that turtles caught by pelagic longliners forage extensively on pelagic prey. Pelagic longliners 
typically fish in oceanic zones outside the continental shelf, where only pelagic prey is available to turtles. The presence of both benthic and pelagic taxa in the longline group and even in the same individual indicates that, in the study area, turtles not only frequent both the sea bottom and the surface for feeding, but also that they move extensively into and out of the continental shelf area.

Further insights on this habitat change are provided by the presence of balanomorph barnacles, since Casale et al. (2004b) observed that the barnacles preferentially occur on turtles frequenting shallow waters. Thus, the lower occurrence of barnacles on turtles caught by longliners than by trawlers in the present study indicates that turtles caught by longliners, though also feeding on the sea bottom, are either not constant frequenters of shallow waters, or have just settled.

All these findings confirm and perhaps expand the previous hypothesis of a transitional stage between the oceanic and neritic stages of loggerhead turtles in the Mediterranean Sea (Laurent et al. 1998). On the other hand, the assumption that pelagic longliners in the Mediterranean catch turtles in their oceanic stage is clearly wrong, and previous and future loggerhead turtle pelagic longline bycatch data should be interpreted accordingly.

Present results also demonstrate that in the Mediterranean Sea, or at least in our study area, a pure oceanic/epipelagic stage is restricted to very small loggerhead turtles outside of the observed size range ( $<25 \mathrm{~cm}$ CCLn-t), which are probably unable to dive down to the sea bottom. A similar finding was reported from the north Adriatic Sea, another important neritic area for loggerhead turtles in the Mediterranean basin, where benthic prey items were found in turtles as small as $30 \mathrm{~cm}$ CCLn-t ( $\mathrm{n}=17$; Lazar et al. in press), while the smallest specimen in the western Mediterranean Sea was $34 \mathrm{~cm}$ ( $\mathrm{n}=54$; Tomas et al. 2001).

In the Atlantic Ocean, an opportunistic foraging strategy of loggerhead turtles presumed to be in the oceanic stage was observed where shallow waters and benthic prey are within reach (Bolten 2003). Such circumstances may be common for juvenile loggerhead turtles in the Mediterranean basin, where oceanic zones are fragmented by coastlines, wide continental shelves, and islands.

In this respect, it is interesting that the smallest loggerhead turtle feeding on benthic prey reported from outside the Mediterranean Sea was from the Gulf of Mexico, a semi-closed basin (32.5 cm; Plotkin 1996). For comparison, smallest sizes recorded from other areas are $59.4(\mathrm{n}=12$; Frick et al. 2001) and $53 \mathrm{~cm}(\mathrm{n}=$ 22; Seney et al. 2003) in the Northwest Atlantic Ocean, $63 \mathrm{~cm}$ in the Southwest Atlantic Ocean $(\mathrm{n}=12$; Bugoni et al. 2003), $47.2 \mathrm{~cm}$ in the Northeast Pacific Ocean
( $\mathrm{n}=14$; converted from $43.5 \mathrm{~cm}$ SCL; Seminoff et al. 2004), and $62.5 \mathrm{~cm}$ in the Southeast Pacific Ocean ( $\mathrm{n}=$ 50; Limpus et al. 2001).

This early switch to benthic prey, when possible, may indicate an advantage of this food in comparison to pelagic prey. Based on growth rate information, Bolten (2003) suggested an advantage, in terms of growth rates, of the habitat shift from the oceanic to the neritic zone for loggerhead turtles in the North Atlantic Ocean. However, costs/benefits of the oceanic and neritic stages are not necessarily the same in the Atlantic Ocean and the Mediterranean Sea, or other factors may be involved too. In fact, in the Atlantic Ocean, loggerhead turtles undergo this habitat shift at a larger size (53 cm; Bolten 2003) than in the Mediterranean Sea.

\section{Opportunistic feeding and loggerhead turtle life history}

As information on the ecology of the loggerhead turtle became available, models of developmental ecology patterns evolved accordingly. Early models described a strict association between developmental stages and marine habitats/zones, with small juveniles in the epipelagic/oceanic zone and large juveniles and adults in the benthic/neritic zone (Miller 1997, Musick \& Limpus 1997). Later, a higher flexibility in the habitat shift during the immature phase was introduced into the model, with an intermediate juvenile transitional stage of variable duration (Laurent et al. 1998, Witzell 2002, Bolten 2003), as well as a more rigorous definition of stages according to oceanographic zones (oceanic and neritic) rather than habitats (pelagic and benthic): oceanic juvenile stage, juvenile transitional stage, neritic juvenile/adult stage (Bolten 2003). However, it is possible that these models reached a level of complexity which is unnecessary and does not fit the reality. Recently, the concept of a neritic stage was seriously challenged, both for juveniles (McClellan \& Read 2007; and also data of Witzell 2002, reinterpreted by us in this new context) and adults (Hatase et al. 2002, Hawkes et al. 2006); who showed that individuals might frequent oceanic zones after having frequented neritic zones at a large size. The results of the present study challenge the concept of both an oceanic stage and of the transitional stage, and in the study area the latter appears to be a long and predominant stage, rather than a short transitional stage between the other 2 stages. Indeed, the well known problem of longline interaction with loggerhead turtles (Lewison et al. 2004) represents evidence that turtles in the oceanic zone are highly attracted to dead animals used as baits. In natural conditions, carcasses are rare in the oceanic zone, but are a more common resource on the seafloor. This attraction 
displayed by small loggerhead turtle juveniles from oceanic zones all over the world indicates an evolutionarily acquired opportunistic foraging strategy starting from a very young age, contrasting with the concept of a strict oceanic stage.

All this evidence indicates that a model describing loggerhead turtle life history in terms of an ontogenetic shift from an oceanic stage to a neritic stage describes part of, but not all, ecological patterns observed so far. First, the concept of an ontogenetic (one-way) habitat shift does not seem to be supported by the evidence. On the contrary, available information indicates that turtles can frequent the oceanic zone whenever it is convenient for them, on the basis of parameters that are still poorly understood. Second, the definition of stages according to oceanographic zones (oceanic and neritic) seems to have some limits, because they do not necessarily describe the ecological role of turtles in terms of which habitat (epipelagic or benthic) they are exploiting, which can change within the same oceanographic zone.

Present results from a specific area with a peculiar ecological situation as well as results from other areas (Hatase et al. 2002, Witzell 2002, Hawkes et al. 2006, McClellan \& Read 2007) indicate that loggerhead turtles are highly opportunistic and exploit any trophic resource within reach over their entire life-span.

Therefore, we propose to relax the current models, and suggest a much more simplified description for the ecology of Caretta caretta (Fig. 4) on the basis of what has been observed in different areas and situations. Under our new model, loggerhead turtles would not

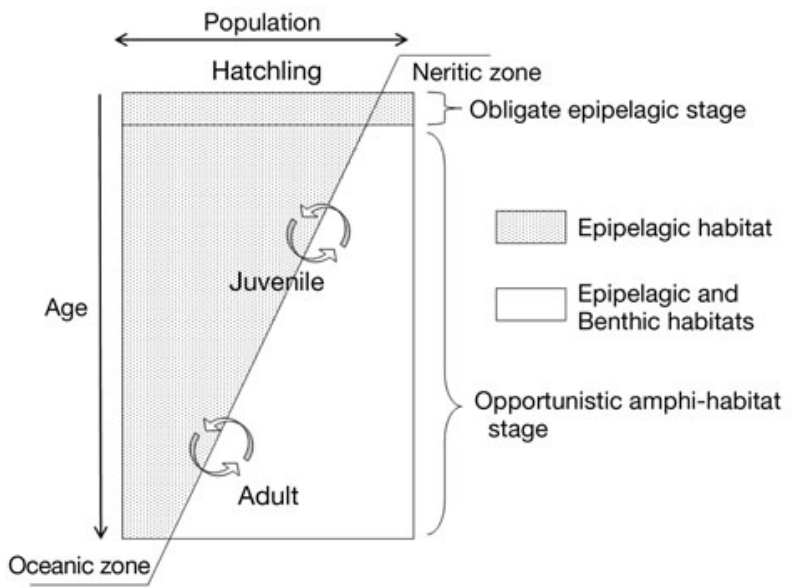

Fig. 4. Caretta caretta. Developmental stages (juveniles vs. adults), ecological stages (obligatory epipelagic vs. opportunistic amphi-habitat), habitats (epipelagic vs. benthic) and oceanographic zones (oceanic vs. neritic), according to the 'opportunistic model' of loggerhead turtle life history (see 'Opportunistic feeding and loggerhead turtle life history'). Rectangle width represents the total of the population at a given age have strict ontogenetic stages, except for a relatively short obligate epipelagic stage in the first period of life (similar to the post-hatchling transitional stage hypothesized by Bolten 2003) in which turtles have no access to benthic habitats due to limited diving capacity, and can frequent any oceanographic zone (neritic or oceanic). In fact, post-hatchlings have a high positive buoyancy and attain buoyancy control at about $1 \mathrm{yr}$ (Milsom 1975). Even then, they have limited dive endurance and, even if they can reach the sea bottom in shallow waters, benthic hunting might be not efficient in terms of costs/benefits. Dive duration increases with body size (Van Dam \& Diez 1997, White 2006, Hochscheid et al. 2007), and once benthic hunting becomes both possible and profitable, loggerhead turtles would enter an opportunistic amphi-habitat stage in which they can exploit all resources through the water column in the area they frequent: epipelagic in oceanic zones, and both epipelagic and benthic in neritic zones. However, as the turtles grow they frequent neritic zones more than oceanic zones, due to an improved diving capacity (Van Dam \& Diez 1997, White 2006, Hochscheid et al. 2007) and to allometric changes in the jaw structure (Kamezaki \& Matsui 1997) that allow the turtle to crush hard-shelled invertebrates, thus allowing for a more and more efficient exploitation of benthic trophic resources. In some cases, turtles would remain permanently in the neritic zone, while in other cases, they would not.

Under this model, differing patterns, such as the one observed in the Atlantic and the western Pacific (a long period of epipelagic feeding in the oceanic zone before moving to the neritic zone where they feed on benthic prey; Bolten 2003, Limpus \& Limpus 2003) versus the one observed in the present study (both epipelagic and benthic feeding for a wide size/age range), and the return to epipelagic feeding after a period of benthic feeding observed in both juveniles and adults in the Atlantic and the western Pacific (Limpus et al. 2001, Witzell 2002, McClellan \& Read 2007), can be seen as particular cases of the same opportunistic amphihabitat stage. These different patterns would be determined by factors acting at the population or individual level, such as oceanographic features, food availability, and predator avoidance.

In conclusion, we recommend not to describe loggerhead turtle life history in terms of ontogenetic shifts and stages associated with oceanographic zones, but instead to describe it in terms of the habitat that individuals frequent for feeding: epipelagic, benthic, or both.

Acknowledgements. We thank the many fishermen who collaborated with the project and the many volunteers who helped in all the activities carried out at the WWF Italy's Turtle Center in Lampedusa. We also thank Francesco Col- 
loca (Dip. BAU, Rome) for bibliographic help, and discussion on gut content analysis. Fig. 1 was prepared with the program Maptool (SEATURTLE.ORG, www.seaturtle.org).

\section{LITERATURE CITED}

Bentivegna F, Ciampa M, Mazza G, Paglialonga A, Travaglini A (2003) Loggerhead turtle (Caretta caretta) in Tyrrhenian Sea: trophic role of the Gulf of Naples. In: Margaritoulis D, Demetropoulos A (eds) Proceedings of the first Mediterranean conference on marine turtles. Barcelona Convention - Bern Convention - Bonn Convention (CMS), Nicosia, Cyprus, p 71-75

Bjorndal KA (1997) Foraging ecology and nutrition of sea turtles. In: Lutz PL, Musick JA (eds) The biology of sea turtles. CRC Press, Boca Raton, FL, p 199-232

Bjorndal KA (2003) Roles of loggerhead sea turtles in marine ecosystems. In: Bolten AB, Witherington BE (eds) Loggerhead sea turtles. Smithsonian Books, Washington, DC, p 235-254

Bolten AB (1999) Techniques for measuring sea turtles. In: Eckert KL, Bjorndal KA, Abreu-Grobois FA, Donnelly M (eds) Research and management techniques for the conservation of sea turtles. IUCN/SSC Mar Turtle Spec Group Publication 4, p 110-114

Bolten AB (2003) Active swimmers-passive drifters: the oceanic juvenile stage of loggerheads in the Atlantic system. In: Bolten AB, Witherington BE (eds) Loggerhead sea turtles. Smithsonian Books, Washington, DC, p 63-78

Bolten AB, Bjorndal KA, Martins HR, Dellinger T, Biscoito MJ, Encalada SE, Bowen BW (1998) Transatlantic developmental migrations of loggerhead sea turtles demonstrated by mtDNA sequence analysis. Ecol Appl 8:1-7

Bowen BW, Abreu-Grobois FA, Balazs GH, Kamezaki N, Limpus CJ, Ferl RJ (1995) Trans-Pacific migrations of the loggerhead turtle demonstrated with mitochondrial DNA markers. Proc Natl Acad Sci USA 92:3731-3734

Bugoni L, Krause L, Petry MV (2003) Diet of sea turtles in southern Brazil. Chelonian Conserv Biol 4:685-688

Burke VJ, Morreale SJ, Standora EA (1990) Comparisons of diet and growth of Kemp's ridley and loggerhead turtles from the northeastern U.S. In: Richardson TH, Richardson JI, Donnelly M (eds) Proc 10th Annu Workshop on Sea Turtle Biology and Conservation. NOAA Tech Memo NMFS-SEFC-278, p 135

Casale P, Laurent L, De Metrio G (2004a) Incidental capture of marine turtles by the Italian trawl fishery in the north Adriatic Sea. Biol Conserv 119:287-295

Casale P, Freggi D, Basso R, Argano R (2004b) Epibiotic crabs and barnacles as indicators of Caretta caretta distribution and movements in the Mediterranean Sea. J Mar Biol Assoc UK 84:1005-1006

Casale P, Freggi D, Basso R, Argano R (2005a) Oceanic habitats for loggerhead turtles (Caretta caretta) in the Mediterranean Sea. Mar Turtle Newsl 107:10-11

Casale P, Freggi D, Basso R, Argano R (2005b) Size at male maturity, sexing methods and adult sex ratio in loggerhead turtles (Caretta caretta) from Italian waters investigated through tail measurements. Herpetol J 15: 145-148

> Casale P, Cattarino L, Freggi D, Rocco M, Argano R (2007a) Incidental catch of marine turtles by Italian trawlers and longliners in the central Mediterranean. Aquat Conserv Mar Freshw Ecosyst 17:686-701

> Casale P, Freggi D, Basso R, Vallini C, Argano R (2007b) A model of area fidelity, nomadism, and distribution patterns of loggerhead sea turtles (Caretta caretta) in the Mediterranean Sea. Mar Biol 152:1039-1049

Dodd CK Jr (1988) Synopsis of the biological data on the loggerhead sea turtle Caretta caretta (Linnaeus 1758). US Fish Wildl Serv Biol Report 88

Frick MG, Williams KL, Pierrard L (2001) Summertime foraging and feeding by immature loggerhead sea turtles (Caretta caretta) from Georgia. Chelonian Conserv Biol 4:178-181

Godley BJ, Smith SM, Clark PF, Taylor JD (1997) Molluscan and crustacean items in the diet of the loggerhead turtle, Caretta caretta (Linnaeus, 1758) [Testudines: Chelonidae] in the eastern Mediterranean. J Molluscan Stud 63: $474-476$

Hatase H, Takai N, Matsuzawa Y, Sakamoto W and others (2002) Size-related differences in feeding habitat use of adult female loggerhead turtles Caretta caretta around Japan determined by stable isotope analyses and satellite telemetry. Mar Ecol Prog Ser 233:273-281

> Hawkes LA, Broderick AC, Coyne MS, Godfrey MH and others (2006) Phenotypically linked dichotomy in sea turtle foraging requires multiple conservation approaches. Curr Biol 16:990-995

Herrera CM (1976) A trophic diversity index for presence-absence food-data. Oecologia 25:187-191

Hochscheid S, McMahon CR, Bradshaw CJA, Maffucci F, Bentivegna F, Hays GC (2007) Allometric scaling of lung volume and its consequences for marine turtle diving performance. Comp Biochem Physiol A 148:360-367

- Hyslop EJ (1980) Stomach content analysis - a review of methods and their application. J Fish Biol 17:411-429

Kamezaki N, Matsui M (1997) Allometry in the loggerhead turtle, Caretta caretta. Chelonian Conserv Biol 2: 421-425

Laurent L, Lescure J (1994) L'hivernage des tortues caouannes Caretta caretta (L.) dans le sud Tunisien. Rev Ecol (Terre Vie) 49:63-86

> Laurent L, Casale P, Bradai MN, Godley BJ and others (1998) Molecular resolution of marine turtle stock composition in fishery bycatch: a case study in the Mediterranean. Mol Ecol 7:1529-1542

Lazar B, Zavodnik D, Grbac I, Tvrtkovic N (2002) Diet composition of the loggerhead sea turtle Caretta caretta in the northern Adriatic Sea: a preliminary study. In: Mosier A, Foley A, Brost B (eds) Proc 20th Annu Symp on Sea Turtle Biology and Conservation. NOAA Tech Memo NMFSSEFSC-477, p 146-147

Lazar B, Gracan R, Zavodnik D, Tvrtkovic N (in press) Feeding ecology of 'pelagic' loggerhead turtles, Caretta caretta, in the northern Adriatic Sea: proof of an early ontogenetic habitat shift. Proc 25th Annu Symp on Sea Turtle Biology and Conservation

- Lewison RL, Freeman SA, Crowder LB (2004) Quantifying the effects of fisheries on threatened species: the impact of pelagic longlines on loggerhead and leatherback sea turtles. Ecol Lett 7:221-231

Limpus CJ, Limpus DJ (2003) Biology of the loggerhead turtle in western South Pacific Ocean foraging areas. In: Bolten $A B$, Witherington BE (eds) Loggerhead sea turtles. Smithsonian Books, Washington, DC, p 93-113

Limpus CJ, De Villiers DL, De Villiers MA, Limpus DJ, Read $M$ (2001) The loggerhead turtle, Caretta caretta in Queensland: feeding ecology in warm temperate waters. Mem Queensl Mus 46:631-645

Margaritoulis D, Argano R, Baran I, Bentivegna F and others (2003) Loggerhead turtles in the Mediterranean Sea: present knowledge and conservation perspectives. In: Bolten 
AB, Witherington B (eds) Loggerhead sea turtles. Smithsonian Institution Press, Washington, DC, p 175-198

McCauley SJ, Bjorndal KA (1999) Conservation implications of dietary dilution from debris ingestion: sublethal effects in post-hatchling loggerhead sea turtles. Conserv Biol 13:925-929

McClellan CM, Read AJ (2007) Complexity and variation in loggerhead sea turtle life history. Biol Lett 3:592-594

Miller JD 1997. Reproduction in sea turtles. In: Lutz PL, Musick JA (eds) The biology of sea turtles. CRC Press, Boca Raton, FL, p 51-81

Milsom WK (1975) Development of buoyancy control in juvenile atlantic loggerhead turtles, Caretta c. caretta. Copeia 758-762

Mortimer JA (1982) Feeding ecology of sea turtles. In: Bjorndal KA (ed) Biology and conservation of sea turtles. Smithsonian Institution Press, Washington, DC, p 103-109

Musick JA, Limpus CJ (1997) Habitat utilization and migration in juvenile sea turtles. In: Lutz PL, Musick JA (eds) The biology of sea turtles. CRC Press, Boca Raton, FL, p $137-163$

Parker DM, Cooke WJ, Balazs GH (2005) Diet of oceanic loggerhead sea turtles (Caretta caretta) in the central North Pacific. Fish Bull 103:142-152

Plotkin PT (1996) Occurrence and diet of juvenile loggerhead sea turtles, Caretta caretta, in the northwestern Gulf of Mexico. Chelonian Conserv Biol 2:78-80

Preen AR (1996) Infanual mining: a novel foraging method of loggerhead turtles. J Herpetol 30:94-96

Seminoff JA, Resendiz A, Resendiz B, Nichols WJ (2004)

Editorial responsibility: Hans Heinrich Janssen,

Oldendorf/Luhe, Germany
Occurrence of loggerhead sea turtles (Caretta caretta) in the Gulf of California, Mexico: evidence of life-history variation in the Pacific Ocean. Herpetol Rev 35:24-27

Seney EE, Musick JA, Morrison AK (2003) Diet analysis of stranded loggerhead and Kemp's ridley sea turtles in Virginia, USA: 2001. In: Seminoff JA (ed) Proc 22nd Annu Symp on Sea Turtle Biology and Conservation. NOAA Tech Memo NMFS-SEFSC-503, p 230-231

Shaver DJ (1991) Feeding ecology of wild and head-started Kemp's ridley sea turtles in south Texas waters. J Herpetol 25:327-334

Tomas J, Aznar FJ, Raga JA (2001) Feeding ecology of the loggerhead turtle Caretta caretta in the western Mediterranean. J Zool (Lond) 255:525-532

Tomas J, Guitart R, Mateo R, Raga JA (2002) Marine debris ingestion in loggerhead sea turtles, Caretta caretta, from the Western Mediterranean. Mar Pollut Bull 44:211-216

van Dam RP, Diez CE (1997) Diving behavior of immature hawksbills (Eretmochelys imbricata) in a Caribbean reef habitat. Coral Reefs 16:133-138

White MG (2006) Marine ecology of loggerhead sea turtles Caretta caretta (Linnaeus, 1758) in the Ionian Sea: observations from Kefalonia and Lampedusa. PhD thesis, University College Cork

Witherington BE (2002) Ecology of neonate loggerhead turtles inhabiting lines of downwelling near a Gulf Stream front. Mar Biol 140:843-853

Witzell WN (2002) Immature Atlantic loggerhead turtles (Caretta caretta): suggested changes to the life history model. Herpetol Rev 33:266-269

Submitted: April 7, 2008; Accepted: August 15, 2008 Proofs received from author(s): November 16, 2008 